\title{
ECONOMIC AND SOCIAL IMPACTS OF COVID-19 IN THE PAST YEAR IN THE EUROPEAN UNION, WITH SPECIAL REFERENCE TO ROMANIA AND HUNGARY ${ }^{1}$
}

\author{
Bernadett Mártha Béresné ${ }^{1}$, Eszter Maklári² \\ ${ }^{1}$ Institute of Accounting and Financial Studies, Faculty of Economics and Business, \\ University of Debrecen, Hungary (orcid 0000-0003-1149-0642) \\ 2Institute of Accounting and Financial Studies, Faculty of Economics ${ }^{1}$ and Business, \\ University of Debrecen, Hungary, student \\ beresne.martha.bernadett@econ.unideb.hu \\ eszter.maklari@gmail.com
}

\begin{abstract}
The COVID-19 pandemic in early 2020 has made a big difference in the lives of all countries around the world. This study is the first part of a 9-months student research work started in 2021 February, based on literature research. Its aim is to present and summarize the major economic and social impacts of the coronavirus epidemic on the macroeconomy and industrial sectors during a one-year period. Our research is mainly based on secondary research methods - and accompanied by data from the most up-to-date statistical databases and other current research studies, we drew conclusions based on our own calculations in connection with the 27 member states of the European Union including Romania and Hungary. As a result of epidemiological measures in national economies, the role of certain sectors has shrunk, while other sectors have undergone tremendous development. The unprecedented spread of teleworking, the reduction in working hours in almost all sectors and the consequent lower wages, and the increase in the unemployment rate, have led to a decline in the value of gross domestic product for all nations, compared to the same period of the previous year. In order to save their country from the collapse of the economy, those responsible for managing them, were also forced to introduce measures that increased the country's state debt and worsened their public finance position. Certain sectors of the economy have been hit hard by the effects of the past year, but there have also been those that have flexibly adapted to the changes. The sectors responded in different ways in each country. It can be argued, however, that the entertainment industry, performing arts and other services that require a personal form of presence have suffered the most from the constraints of the past year. But in the field of information and communication, there have been positive developments in many countries using the opportunities offered by information technology. However, changes during the pandemic period have led to a further increase in wealth inequalities in our world. As a result, unfortunately, more and more people are falling into deep poverty and the number of wealthy people is also increasing. The transformation of consumers' values and income situation is having an impact on all sectors of the national economy. The question arises: when will declining companies be able to recover, will they be able to make the profits typical of their pre-epidemic management, and if so, when? Can we live in the future the way we lived in the past? Whether humanity will realize, that the growing differences between continents, countries, people are only creating larger controversies, and at last we do not only realize, but act in a responsible way for the sake of equality for all.
\end{abstract}

Keywords: Covid-19, European Union, Romania, Hungary, socio-economic impacts JEL Classification: EOO

„SUPPORTED BY THE ÚNKP-20-NEW National EXCELLENCE PROGRAM OF THE Ministry FOR INNOVATION AND Technology from the source of the National Research, Development and InNovation fund." 


\section{The appreciation of the role of the local economy}

We live in the age of globalization and networking. From an economic point of view, through cross-border infrastructure networks, a country has not only trade, but also economic and even cultural relations with several other countries. That is why the COVID-19 pandemic, which appeared in the spring of 2020, has spread almost everywhere in the world, and thereby has brought about significant changes in the social and economic life of national economies. This tiny virus has shown, that everything in our world is connected to everything, and how much a tiny change can affect the lives of the whole world. (CSIZMADIA, 2020)

As a result of the pandemic, international trade turnover fell by almost a fifth. Following the outbreak, supply disruptions at companies have become commonplace. The shortage of materials occurred especially in companies that use just-in-time inventory management and procure their production equipment from distant countries. (PÉNZÜGYI SZEMLE, 2020)

As a result of travel and transportation restrictions, regional supply chains have come to the fore in global supply chains, and there has been an increasing emphasis on protecting national markets in all countries of the European Union. (CSIZMADIA, 2020)

\section{Impact of the COVID-19 pandemic on the macroeconomy}

Figure 1 shows the changes in the value of some macroeconomic indicators in Romania, Hungary and the 27 Member States of the European Union, for the period 2017-2020. It can be stated that, considering the GDP growth rate, both Romania and Hungary have performed above the EU-27 average in recent years. In 2020, compared to 2019, GDP decreased by $-3.9 \%$, in Hungary it fell by $-5.0 \%$, while in the EU it fell by $-6.2 \%$ However, the rate of decline was almost the same in Romania and the Community (RO: 8 percentage points, EU-27: 7.8 percentage points), but Hungary had the highest value at 9.6 percentage points. Regarding the annual inflation rate, we see a continuous decrease in Romania and the EU-27 from 2018, which is favorable for the economies, but in Hungary there is a gradual increase from 2017, which will have a cumulative negative effect on the people. In terms of the unemployment rate, during the period under review, Hungary and Romania subsequently showed lower values than the community. Examining the general government balance, we can state that in the EU it was below $-1 \%$ of GDP every year, and both in Romania and Hungary it was similar. However, the year 2020 hit the economies of both countries very badly. Hungary experienced a larger decline of 6.5 percentage points compared to 2019 than Romania (5.3 percentage points), despite the fact that the general government balance of the latter nation was less favorable in 2020 (9.8). Overall, macroeconomically, the changes brought about by the pandemic in 2020, have put a significant strain on the national economies. This is also supported by the fact that between 2017 and 2020, the government debt ratio in Romania, as a percentage of GDP, increased from $35.4 \%$ to approximately $45 \%$. 


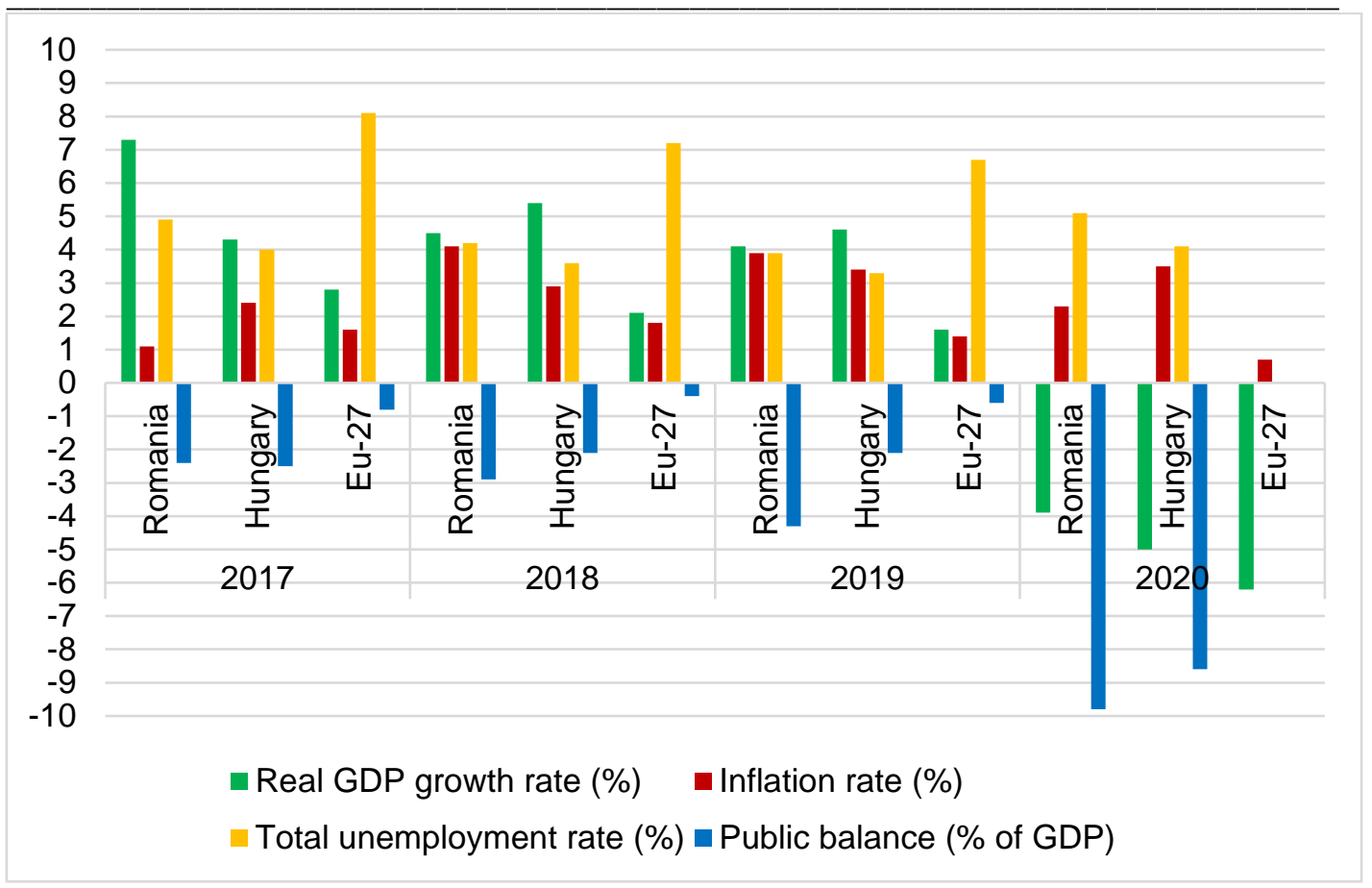

1. Figure: Development of macroeconomic indicators for Romania, Hungary and the EU-27, in 2017-2020

Source: Own editing based on the data of EUROSTAT (2021b; 2021c); MKI (2021); Papp (2021); Csiki (2021)

The ratio of Hungarian public debt changed to a much greater extent, as its rate reached an unprecedented peak of $81.2 \%$, which meant a 15.8 percentage point deterioration, which is 1.5 times of that in Romania. However, on average in the EU-27, public debt can reach $94 \%$ of GDP, said one of the leading economists of the International Investment Bank. (Index, 2021)

Among the Central and Eastern European Member States, the Czech Republic has introduced the largest fiscal incentive package in the region as a result of the coronavirus pandemic, accounting for $14 \%$ of GDP, compared to $8 \%$ in Hungary, $6 \%$ in Slovakia, $5 \%$ in Bulgaria, and $4 \%$ in Romania. The central banks of Hungary and Romania have also launched quantitative mitigating programs, which, combined with other liquidity measures, have significantly mitigated the risk of a financial crisis (by averting the potential threat of frozen debt markets and blocking bank lending).

This economic crisis cannot be described as a typical one, or even similar to the 2008 crisis. The global financial crisis of 2007-2008 and its effects on the industrial sectors were detailed by Kiss (2017) in his study.

Table 2 shows an analysis by Elliott Auckland, chief economist at the Budapest-based International Investment Bank (IIB). It turns out that in 2021 and 2022 the GDP growth rate in the examined regions will change in a positive direction, and as a result, Hungary's GDP may reach the level of 2019 in the third quarter of 2022. This can be almost a year earlier than in the rest of the European Union, which is expected to reach its 2019 performance only in the second quarter of 2023. Now Romania, overtaking the above, could reach it as early as in the second quarter of 2020 .

Table 2. Expected GDP growth values (\%) 


\begin{tabular}{|l|c|c|c|}
\hline \hline \multicolumn{1}{|c|}{ Designation } & 2021 & 2022 & Restore GDP to 2019 levels \\
\hline Hungary & $4.3 \%$ & $4.7 \%$ & $\mathrm{Q3}, 2022$ \\
\hline Romania & $3.5 \%$ & $4.1 \%$ & $\mathrm{Q} 2,2022$ \\
\hline EU-27 & $4.1 \%$ & $3.0 \%$ & $\mathrm{Q} 2,2023$ \\
\hline
\end{tabular}

Source: Index (2021)

\section{Impact of the COVID-19 pandemic on the labor market}

The pandemic has changed the way the whole world works, so it has also had a significant impact on people's lifestyles. In order to reduce social contacts, more and more companies have introduced work from home. According to the EUROFOUND survey, in 2020, 1/3 (33.7\%) of workers in the 27 Member States of the European Union worked exclusively from home, 38.9 hours a week, $14.2 \%$ spent alternately half of their working time at home and half at their employer, while $52.1 \%$ of them worked outside their home (at the employer's premises or other external locations). The proportion of people working in the home office in $2020(33.7 \%)$ is quite higher than in previous years (Table 1), thus the modifying effect of the COVID-19 pandemic in the field of work can be strongly felt. (AHRENDT ET AL, 2020) Based on the research results of EUROFOUND, the home office is closely correlated with the level of education. In 2020, $74 \%$ of workers with higher education, $34 \%$ of those with secondary education, and only $14 \%$ of primary school graduates worked from home in 2020. Most of those working in education (more than $60 \%$ ), finance $(50-60 \%)$ and administration (40-50\%) worked through telework. However, working from home has also occurred in industry, construction, agriculture, transportation, commerce, and health care. In terms of gender, more women worked from home than men. Telework was most popular among workers over the age of 65 , followed by members aged 15-29, followed by those aged 30 49. The fewest teleworkers came from the 50-64 age group. Surprisingly, the majority were teleworkers who do not have a dependent child. The number of people working exclusively from home varied considerably per Member State. In Croatia, Poland, Slovakia, Bulgaria and Hungary, about one fifth of workers, in France, Spain, Italy, Ireland more than $40 \%$ of employees, and in Belgium more than $50 \%$ teleworked. (AHRENDT ET AL, 2020)

Prior to the outbreak of COVID-19, home office use was least prevalent in Romania, among European Union Member States. In 2010, 0.1\% of Romanian workers and in 2019, 0.6\% worked telecommuting. Apart from Romania, of the Member States, Bulgaria, Cyprus and Italy had less than $2 \%$ work from home. Although Romania has so far been at the bottom of the EU list of teleworkers, the proportion of people working from home has also increased since the appearance of the coronavirus. According to a EUROFOUND survey, in July 2020, $24 \%$ of employees worked in a home office. (PENGÖ, 2020)

Table 1: Proportion of home workers in the 27 Member States of the European Union

\begin{tabular}{|c|c|}
\hline Years & $\begin{array}{c}\text { Proportion of home workers in the 27 Member } \\
\text { States of the European Union }\end{array}$ \\
\hline 2010 & $11.2 \%$ \\
\hline 2011 & $11.4 \%$ \\
\hline 2012 & $11.7 \%$ \\
\hline 2013 & $11.8 \%$ \\
\hline 2014 & $11.7 \%$ \\
\hline 2015 & $12.9 \%$ \\
\hline 2017 & $13.1 \%$ \\
\hline 2018 & $13.1 \%$ \\
\hline 2019 & $13.5 \%$ \\
\hline
\end{tabular}

Source: Own editing based on (EUROSTAT, 2021a) 
In addition to the proliferation of working from home, there are a number of changes in the labor market. As a result of the coronavirus, more and more workers were employed parttime. In the European Union, the working hours of employees has fallen by an average of $3.7 \%$. The largest change was in Italy, where the employment time of employees fell by $9.7 \%$, while in Slovakia it fell by $8.7 \%$, and in Greece and Austria, by $7.9 \%$. Finland is an exception to the general trend, with an increase of $0.2 \%$ in employee working time. The decline in working hours occurred to varying degrees in different sectors. The effects of the COVID-19 pandemic are most pronounced in trade, catering industry and construction. Employment time decreased by $52 \%$ in the above sectors, $48 \%$ in transportation, $47 \%$ in industry, $36 \%$ in services and education, $30 \%$ in the financial sector and $24 \%$ in the agricultural sector, while there was a $23 \%$ decrease in employment time in health care workers and $21 \%$ in the public sector. (AHRENDT ET AL, 2020)

Part-time employment has become much more common for women than for men. As a result of the coronavirus, women's working hours were reduced by an average of $5.2 \%$, while those of men were reduced by $4.9 \%$. In Italy, Slovakia, Greece, Austria and Portugal, the emergence of the coronavirus has had a particularly large impact on women's lives. On average, women's working hours fell by $10.3 \%$ in Italy, $10.2 \%$ in Slovakia, $8.3 \%$ in Greece, $7.8 \%$ in Austria and $6.3 \%$ in Portugal. Men's employment time fell the most in Italy (-9.3\%), Austria (-8.0\%), Hungary (-7.9\%) and Malta and Slovakia (both -7.6\%). (EUROSTAT, 2020) Also, according to the EUROFOUND questionnaire survey, $10 \%$ of respondents left the labor market after the outbreak of COVID-19. $80 \%$ of them became unemployed, while $20 \%$ became inactive. Those in the latter group retired, became ill, became students, or became homemakers. Altogether, $10 \%$ of employees lost or left their jobs voluntarily. Only $3 \%$ is the proportion of those who entered the labor market after the COVID-19 pandemic became widespread. (AHRENDT ET AL, 2020)

In 2020 the coronavirus affected the most the labor markets of Spain, Cyprus and Greece. In Spain, 16\% of responding workers lost their jobs, in Cyprus 15\% and in Greece 14\%. 12\% of respondents in Hungary and Latvia, 9\% in Bulgaria, France, Portugal, Romania, Ireland, Lithuania, Poland and Croatia, $8 \%$ in Finland, Denmark and Luxembourg, Austria, Estonia, Belgium, Slovenia and $7 \%$ of respondents in Italy, $5 \%$ in Germany, $4 \%$ in the Czech Republic, Slovakia, Malta and the Netherlands, and $3 \%$ in Sweden became unemployed following the outbreak of COVID-19. There is a small difference in terms of gender. On average, $9 \%$ of women and $8 \%$ of men in the European Union became unemployed. In particular, the pandemic changed the employment situation of workers aged 18-34, with $11 \%$ of women and $9 \%$ of men losing their jobs within the group. Besides the young age group, workers over the age of 50 suffered the most from the spread of the pandemic $8 \%$ of both women and men in this age group became unemployed Members of the 35-49 age group were least affected by the pandemic from a labor perspective. The employment situation of $9 \%$ of women and $6 \%$ of men changed as a result of the epidemiological situation. Research shows that more entrepreneurs have lost their jobs than employees in the European Union. Those with a secondary or lower education typically have a higher proportion of people who become unemployed than those with a higher education. (AHRENDT ET AL, 2020)

In Romania, the unemployment rate was $4.8 \%$ in April 2020, and this rate was down 7 percentage points in February. According to the Portfolio, the last time the country had such a high unemployment rate, was in the second half of 2017 . According to a statement by the Romanian Institute of Statistics, in April 2020, the number of people officially registered as jobseekers, among members of the 15-74 age group, was 432,000 . That number was less by 18,000 a year earlier and less by 59,000 two years earlier. Unlike the EU average, in Romania in the spring of 2020 the unemployment rate was higher for men $(5.4 \%)$ than for women (3.9\%). The value of the latter rates did not include unemployed people whose employment contracts were suspended after the onset of the pandemic. The number of persons belonging to the latter group in May 2020 was 430 thousand. (MTI, 2020) 
According to the Statista, as of July 3, 2020, some 102,830 employment contracts have been suspended in Romania, due to the outbreak of COVID-19. In this country, tourism and catering services were the biggest losers in the pandemic, as 24,464 people could not work in that area after the outbreak. While 20,543 jobs in the manufacturing industry, a total of 8,996 jobs in the retail, trade and automotive industries were suspended. (SAVA, 2020)

\section{The effect of coronavirus on the development of different sectors}

Table 3 shows the change in the volume of gross value added in 2020 compared to the data of 2019, in the average of the 27 countries of the European Union, as well as in Hungary and Romania. The consequence of the COVID-19 pandemic is that in the whole quarter of 2020 , compared to the same period of the previous year, the value added of the European Union economy decreased by $4.2 \%$ on average, while Romania by only $2.1 \%$, at the same time Hungary by $6.9 \%$. Behind these changes, we can see which sectors were most affected by the crisis. Not only in the average of the community as a whole, but also in Hungary, and not to mention Romania (-22.5), the arts, entertainment, leisure and other service sectors were most affected by the decline. Wholesale and retail trade, transportation, accommodation and catering services in the EU fell by more than $10 \%$, but this sector in Romania was not so hard hit by the virus, it was able to adapt flexibly to the situation. In Romania, the area of production was the sector that had a harder time responding to the effects of the crisis. In Hungary, there was also a decline of over $10 \%$ in professional, scientific and technical activities and in administrative activities. However, in 2020 the EU27 and Romania also saw positive changes compared to the previous year in terms of gross value added in real estate, information and communication, and in the sectors of public administration, education, health, defence and social work. Unfortunately, this cannot be said of Hungary, in fact, in 2020 the country was unable to increase the value of its gross value added production in any sector compared to 2019. In addition to the three sectors mentioned above, Romania has also achieved growth in the following sectors: construction, finance and insurance, professional scientific and technical activities, administrative and support service activities. Remarkable positive growth of $14.3 \%$ in information and communication.

Table 3: Volume change of gross value added in the whole quarter of 2020 compared to the same period of 2019 in the average of the EU-27 countries, Hungary and Romania

\begin{tabular}{|l|c|c|c|}
\hline \multicolumn{1}{|c|}{ Measure } & EU-27 & Hungary & Romania \\
\hline Agriculture, fishing and forestry & -1.3 & -3.2 & -9.2 \\
\hline Industry (except construction) & -6.1 & -7.1 & -9.2 \\
\hline Manufacturing & -6.5 & -7.1 & -11.6 \\
\hline Construction & -1.6 & -8.9 & 6.7 \\
\hline Financial and insurance activities and technical activities; & -1.4 & -2.3 & 2.8 \\
\hline $\begin{array}{l}\text { Professional, scientific and } \\
\text { administrative and support service activities }\end{array}$ & -6.9 & -11.1 & 4.6 \\
\hline $\begin{array}{l}\text { Public administration, defence, education, human health } \\
\text { and social work activities }\end{array}$ & 1.4 & -2.5 & 2.5 \\
\hline $\begin{array}{l}\text { Wholesale and retail trade, transportation, } \\
\text { accommodation and food service activities }\end{array}$ & -11.5 & -12.4 & -3.0 \\
\hline $\begin{array}{l}\text { Arts, entertainment and recreation; other service } \\
\text { activities; activities of household and extra-territorial } \\
\text { organizations and bodies }\end{array}$ & -14.6 & -12.4 & -22.5 \\
\hline Real estate activities & 0.8 & -8.2 & 1.3 \\
\hline Information and communication & 1.4 & -0.5 & 14.3 \\
\hline Average & -4.2 & -6.9 & -2.1 \\
\hline
\end{tabular}

Source: Result of own calculation, based on EUROSTAT 2021d data 


\section{What lies ahead of us in the future?}

One of the most serious consequences of the spread of the coronavirus is the further intensification of wealth inequalities. The non-profit organization Oxfam estimated in April 2020 that the COVID-19 pandemic could push nearly half a billion people, 1/16 of humanity, into deep poverty. Huge income inequalities are also shown by a study by Knight Frank, according to which the number of billionaires in the world is expected to increase by $27 \%$ over the next 5 years, further increasing social inequality among members of society. The number of people in the latter group will grow at the fastest pace in 6 Asian, 5 European and 3 African cities. Sweden is among the top 10 countries in the European Union in terms of the growth rate of the rich, and also Romania, not surprisingly, based on its analysis so far. (ÁRGYELÁN, 2020) The future impact of this negative process will only further strengthen the economic model in which our current economy operates, which is no longer sustainable. The world should think in an economic model in which the more realistic distribution of goods takes place with emphasis on natural goods and factors. To do this, on an individual level, personal responsibility must be strengthened in everyone. The resurgence of this personal responsibility has already shown its effect in defence against the pandemic. Going further, we consider it important to spread the attitude that everyone should consume only what and how much they need. Even though we live in a consumer society, let's live much more consciously and find our way back to the natural foundations instead of further increasing the distance between people using artificial intelligence. Let's create a world we would love to live in. We can start this by changing our previous habits on an individual level, reviewing them, and not wanting to adapt to expectations, established patterns, but to get to know ourselves and live accordingly. We may realize that we can cope with much less material goods and then get more for others!

It is uncertain, how long we can still feel the adverse social, economic and employment effects of the COVID-19 pandemic in the European Union. According to an analysis by Boston Consulting Group, the biggest hit of the pandemic affected international trade and had a lasting impact on it. Even if we manage to restore the 2019 status in this field by 2023 , for sure, the map of the world economy will be significantly rearranged. Not only have the economies of many nations become unstable during this period, but geopolitical and domestic tensions have also increased, and a positive solution remains to be found. (PÉNZÜGYI SZEMLE, 2020) Nevertheless, according to a EUROFOUND survey, 68\% of EU respondents were optimistic about their future. (AHRENDT ET AL, 2020)According to the report of the World Economic Forum, Hungary's preparedness for the next decade is just sufficient. Only our digital infrastructure preparedness is more favorable than that of the other three Visegrad countries. The most important aspect of competitiveness is to ensure a long-term vision for the economic operators. Without it, the willingness of the economic sector to take risks and the willingness to invest will decrease significantly, which will have an adverse effect on the further development of the economy. Furthermore, maintaining a single tax rate system in the event of a crisis will further worsen the economy's chances of recovery, so it would be worthwhile to reintroduce the multi-key form of taxation to the country with a fairer burden-bearing in mind. (PORTFOLIO, 2020)

\section{References}

1. Ahrendt D. - Cabrita J. - Clerici E. - Hurley J. - Leončikas T. - Mascherini M. - Riso S. Sandor E. (2020): Living, working and Covid-19. Publications Office of the European Union. European Foundation for the Improvement of Living and Working Conditions, Luxembourg, 68 p. ISBN 978-92897-2117-2, DOI: 10.2806/467608

2. Árgyelán Á. (2020): The impact of the coronavirus: millions sink into deep poverty, and a handful of people have never been so rich. Portfolio. Downloaded: March 11, 2021 https://www.portfolio.hu/befektetes/20200815/a-koronavirus-hatasa-milliok-sullyednekmelyszegenysegbe-egy-mareknyi-ember-meg-sosem-volt-meg-ilyen-gazdag-444942 
3. Csiki G. (2021): The government's money dispersion had its effect: there has never been such a deficit in the Hungarian budget. Portfolio. January 11, 2021 Downloaded: April 1, 2021 https://www.portfolio.hu/gazdasag/20210111/hatott-a-kormany-penzszorasa-soha-nem-volt-megekkora-deficit-a-magyar-koltsegvetesben-464790

$4 . \quad$ Csizmadia N. (2020): The future has changed for a while - a new world order after the coronavirus pandemic. Világgazdaság. Downloaded: March 11, 2021

https://www.vg.hu/velemeny/elemzes/a-jovo-egy-idore-megvaltozott-uj-vilagrend-a-koronavirusjarvany-utan-2-3144142/

5. EUROSTAT (2020): Fall in hours worked more visible for women in Q1 2020. Downloaded: March 11, 2021

https://ec.europa.eu/eurostat/web/products-eurostat-news/-/DDN-20200714-1

6. EUROSTAT (2021a): Prozent der zuhause arbeitenden Erwachsenen nach Geschlecht, Altersgruppe, Zahl der Kinder und Alter des jüngsten Kindes. Downloaded: March 11, 2021

https://appsso.eurostat.ec.europa.eu/nui/show.do?dataset=lfst_hhwahchi\&lang=de

7. EUROSTAT (2021b): European Commission Eurostat. National Accounts. Data. Downloaded: April 5, 2021 https://ec.europa.eu/eurostat/web/national-accounts/data

8. EUROSTAT (2021c): Government finance statistics/hu. Kormányzati pénzügyi statisztika. Downloaded: April 1, 2021 https://ec.europa.eu/eurostat/statistics-explained/pdfscache/16018.pdf

9. EUROSTAT (2021d): European Commission Eurostat. Products Dataset. Gross Value added. Downloaded: April 5, 2021 https://ec.europa.eu/eurostat/web/products-datasets/-/teina400 r2 10. Index (2021): The Hungarian economy may recover faster than the rest of EU. January 19, $2021 \quad$ Downloaded: April 2021 https://index.hu/gazdasag/2021/01/19/nbb fokozgazdasz elemzes elliott auckland/

11. Kiss A. (2017): An Empirical Analysis of the Effects of the 2007-2008 Financial Crisis on Changes in the Value Creation of Firms in Individual Industrial Sectors, Annals of the University of Oradea Economic Science, Vol. 26., No. 1., pp. 405-412.

12. MKI (2021): Romania's economic situation and bilateral trade relations. Hungarian Chamber of Commerce and Industry February 18, 2021 Downloaded: April 5, 2021 file:///C:/Users/user_2/Downloads/roman-gazdasagi-helyzet-ketoldalu-kapcsolatok.pdf

13. MTI (2020): Romania's unemployment rate has jumped to a 2.5-year high due to the coronavirus. Portfolio. Downloaded: April 1, 2021

https://www.portfolio.hu/gazdasag/20200603/25-eves-csucsra-ugrott-a-roman-munkanelkulisegi-rataa-koronavirus-miatt-435250\#

14. Papp Zs. (2021): State debt is at its peak. Népszava. January 11, 2021 Downloaded: April 5, 2021. https://nepszava.hu/3105565_csucson-az-allam-tartozasa

15. Pengő Z. (2020): The proportion of teleworkers in Romania has increased 40 times in one year. MASZOL. Downloaded: April 1, 2021

https://maszol.ro/gazdasag/134988-egy-ev-alatt-40-szeresere-n-tt-a-tavmunkat-vegz-romaniaidolgozok-aranya

16. Pénzügyi Szemle (2020): International trade could fall by a fifth due to the coronavirus pandemic. Downloaded: March 11, 2021

https://www.penzugyiszemle.hu/tanulmanyok-eloadasok/otodevel-eshet-vissza-a-nemzetkozikereskedelem-a-koronavirus-jarvany-miatt

17. Sava, J. A. (2020): Number of employment contracts postponed because of the coronavirus (COVID-19) pandemic in Romania as of July 3, 2020, by industry. Statista. Downloaded: April 1, 2021 https://www.statista.com/statistics/1110437/employment-contracts-postponed-during-covid-19romania/ 